\title{
Curriculum, caring for the Earth, and planetary responsibility
}

\author{
Thiago Ranniery ${ }^{1}$ (D)
}

Accepted: 25 January 2021 / Published online: 21 June 2021

(C) UNESCO IBE 2021

\begin{abstract}
This text is a simultaneously personal and political commentary on those who inhabit the border between worlds, such as those now at war in a viral assemblage. Starting from a general intention of shifting curricular responses away from instrumental and technical solutions toward cultivating the ability to act and think in times of uncertainty, the argument developed here is that the need to respond to the Covid-19 crisis involves repositioning curriculum and responsibility as caring for the Earth. The article creates a dialogue between cosmoecological alliances of different onto-epistemological practices and formulations that expand the ethics of care for other-than-humans. The central issue is to defend reimagining the relationship between curriculum and subjectivity within interdependent stories on the planet. We do this in order to develop a sort of vaccine to prevent curricular imagination from becoming captive to the geometric coordinates of the economization of life.
\end{abstract}

Keywords care ethics · Covid-19 $\cdot$ curriculum $\cdot$ responsibility $\cdot \operatorname{cosmoecopolitics} \cdot$ otherthan-human $\cdot$ pandemic

To think the war we find ourselves waging is not only a duty, a responsibility, an obligation, it is also a necessity, a constraint that, like it or not, directly or indirectly, no one can escape. Henceforth more than ever. And I say "to think" this war, because I believe it concerns what we call "thinking".

(Derrida 2008, p. 29)

Brazil, April 2020. When I started writing this article, the country had already recorded around twenty thousand cases and more than three thousand confirmed deaths during the first month that Covid-19 officially started circulating in Brazil. UNESCO's data also reported that schools in 192 countries had closed, and ninety percent of the world's student population had been affected (UNESCO 2020). As a member of the Board of the Faculty of

Thiago Ranniery

t.ranniery@gmail.com

1 Federal University of Rio de Janeiro, Avenida Pasteur, 250, Urca, Rio de Janeiro, Brazil 
Education at a Brazilian public university, I had never seen such a state of terror, fear, and panic among coworkers and students - and I strongly believe no one of my generation had. Whether it was by those who lived through the Brazilian military dictatorship in the Sixties and Seventies, those who expected a deepening of an anti-democratic political agenda as a result of the troubling marriage between neoliberal and neoconservative demands upon the election of President Jair Bolsonaro, or those who witnessed the devastating machinery of murderous policies transforming peripheral urban areas into impoverished, bloody deserts, the feeling expressed was almost always of not knowing what to do. With no early warning, we were engulfed by the global escalation of the epistemic and ontological uncertainty of the viral cloud of which Lowe (2010) wrote. Instead of waiting for the next end of the world, the mythocosmological variation of pandemic imagery, in the words of Lynteris (2019), took on a form.

Suddenly, the circulation of the Sars-Cov-2 virus escaped our knowledge production and forced us to pay attention to the crossing of multiple points of view and infrastructural arrangements as well as to redraw the relationship between humans and other-than-humans. (I use this expression to avoid the negative sense of nonhuman and, at the same time, to include not only other creatures but also the possibility of an othered human.) If there is anything that pandemics do, it is to undermine the pretension of humanity's dominance, the foundation of the modern illusion of pedagogical training. It is not without reason that Berardi (2011) notes that the uncertainty in the face of the unknown will be converted into a threat to the humanistic program, a conversion that ends up jamming the machinery of political imagination. So, how is it possible to unlock curricular imagination in the face of the Covid-19 crisis and, at the same time, live with the Brazilian political processes that have been transforming the induced state of insecurity into an outspoken celebration of death? How can curricular thinking respond without paving the way for the overexploitation of the Earth and its conversion into raw material and energy, which also translates into the desire that the end of the world is not or may not be so far away? Wouldn't it be better to go straight to the point and write, as Latour (2002) once suggested, in terms of a war of the worlds?

I explore these questions because I wish to separate responsibility from the abstract moral duty of the curriculum in the face of the crisis the pandemic has brought about. Echoing Derrida's (2008) epigraph, I understand responsibility as the curriculum's need to think about this war we are in and the crisis that stems from it in order to develop skills for ethical engagement, a social pragmatics, and a radical policy. It is necessary to take seriously Virginia Woolf's exhortation, invoked by Haraway (2016, p. 47): “Think we must! We must think". In effect, I propose to shift curricular responses from designing educational (re)solutions to the horizon of replies to other-than-human alterity. I do so because, at least in Brazil, the public debate on education has been rapidly reduced to what to do and how to do it, and sometimes echoes the technopolitics of the guidelines of multilateral organizations. For instance, a recent position statement from the National Council of Education (CNE 2020) in Brazil on the suspension of school schedules in the country quotes a document from the Organization for Economic Cooperation and Development (OECD 2020). Without disregarding the importance of an "education response to the Covid-19 pandemic" (OECD 2020, p. 5), the speed of the response crystallizes the conditions that gave rise to the possibility of the crisis, seeks to integrate the disease into the existing educational framework, and can obliterate any means of engaging curriculum and responsibility.

In my view, the pandemic opens the possibility of thinking about the educational experience in addition to an instrumental notion of response and political action. I argue that 
the need to respond to the Covid-19 crisis involves repositioning curriculum and responsibility as caring for the Earth. To illustrate, I briefly recount a personal experience, focusing on the possibilities of "nonhierarchical modes of coexistence between different practices in their "inventions of nonequivalence, among the diverging values and obligations" (Stengers 2010, p. 356). Then, I create a dialogue between cosmoecological alliances of different onto-epistemological practices and formulations that expand the ethics of care for other-than-humans. Since we are facing a unique experience of loss, and since, as Butler (2004) once stated, mourning may bring back relational ties and has ethical implications, the final section returns to the issue of curriculum response as subjective production involved in planetary interdependence.

\section{Inside the belly of the monster: Situating the argument}

My argument is simultaneously a personal and political commentary on those who inhabit the border between worlds, such as those who are now at war in what I call a viral assemblage. Although Fox (2020) suggested thinking of the pandemic as an epidemic assemblage, it may be more thought-provoking to write in terms of a viral assemblage becauseas I hope to suggest - the binary division of we "humans" versus viruses is overly simplified (viruses depend on hosts) and because it allows multiple instances and agencies to be considered.

I begin with a brief story about my personal experience in the curriculum field in Brazil. I was originally trained as a marine biologist. My area of specialization was trophic ecology and the reproductive biology of fish along the coast of the state of Sergipe, in Northeastern Brazil. Although the days of fieldwork, sailing on seas and rivers, were very seductive, what interested me the most were questions in the ichthyology laboratory that my supervisor called conceptual. I followed this academic path for a few years with three companions. Besides my supervisor, our fieldwork depended on José, the fisherman who captained the boat on which we traveled the river estuaries. José and my supervisor had been doing collaborative research for over 20 years. My other companion was the wellknown fish carapeba (Diapterus rhombeus), whose name in the Tupi language refers to its flattened body. I think, here, of the epistemic cultures of Knorr-Cetina (1999). Laboratories not only modify the organisms they manipulate through experimental systems, but they also create socialities that remake their scientists. Somehow, the intertwined encounter with these companions transformed my own way of thinking.

Diapterus rhombeus is a silver fish widely present in seas and estuaries of the Western Atlantic from Florida to Brazil and common throughout Central and South America. Due to its abundance, the carapeba is important to the livelihood of artisanal fisherman like José. Since peba is fisherman slang for "common man", my advisor joked that the species should just be called "common fish" or "nobody fish". During these years, I dissected a few hundred bodies of Diapterus rhombeus, opened up their stomachs, and prepared slides of their gonads for study. While the literature registered the progressive importance of the species as a potential economic resource, we appealed to those "nobodies", who found a place to breed in the estuaries, so that their bodies could tell us something about a problem in which ichthyologists, fishermen, and fishes were immersed: the health of rivers. This conversation between us scientists and the bodies of the carapeba cast us in the middle of transduction relation circuits in order to attend to the emergence of this problem: bodies corroded from the inside, gonads deteriorated. (The concept of transduction was developed 
by Simondon (1992); transduction is a way of thinking about how communication is an affective activity of semiotic-material propagation through bodies (Helmerich 2009; Myers 2015).

One day, when visiting the laboratory, José, seeing me dismayed by the fish's deformities, said: "Look, this is killing the fish from inside. One day, son, no matter how good a sailor someone is, the boat will capsize. And people will also drown, like this, from inside".

I recount this personal story because a year ago I took over the coordination of a curriculum research program that follows teachers, scientific communicators, journalists, health workers, biologists and doctors around Brazil's triple viral epidemic (dengue, zika, and chinkungunya), whose vector is the Aedes aegypti mosquito. My proposal seeks to echo Weaver's provocation $(2019$, p. 7) that curriculum studies must turn to matters of science and that "we [curriculum scholars] need to become the educators of the scientists". However, my own wish is for transdisciplinary relationality to take shape in the curriculum field as "a new mutuality based on common interests in livability" (Tsing 2015a, p. 5). I have been partially inspired by Latour (2011) to accompany scientists not just for their final products but for the entire assemblage of times and places where such productions are being enacted. Latour (2017) insists that it "is impossible to understand what is happening to us without turning to the sciences... and yet, to understand them, it is impossible to settle for the image offered by the old epistemology" (p. 4). I said "partially" inspired because the proposal for this program is due mostly to Povinelli's suggestion (2016) to frame the virus as a figure of what she calls "geontopower", the same way of the late liberalism governs not only the distinction between life and death, but between life (bios) and nonlife (geos).

I recognize the differences between these approaches, but for now, those differences are less important than how this research experience allowed me to start creating the scenario in which my argument is situated. Covid-19 and the associated crisis are not isolated events. It is as if locally concentrated apparitions like the zika epidemic in Brazil, the Ebola outbreak in West Africa, severe acute respiratory syndrome (SARS), Middle East respiratory syndrome (MERS), a variety of avian flus, the swine flu, and the reappearance of yellow fever and African swine fever finally gained an analogous global version right in the middle of our planetary agora. This is a consequence of a strange pact in "the belly of the local/global monster" (Haraway 1992, p. 297) between changes induced on the one hand by developers' practices, industrial agriculture's use of soil, and livestock production on a large scale and, on the other, by urban expansion and deficiencies in public healthcare and environmental sanitation. Wallace's (2016) unpacking of the complex layers of this virological topology is useful for suspending "the metabolic rift between ecology and economy, and between the urban and the rural and wilderness" (Wallace 2020, p. 20). My argument begins where Wallace's (2020, p. 46) ends, by suggesting that the "way out is nothing short of birthing a world (or perhaps more along the lines of returning back to Earth".

A variation of this theme in my research is reflected in the work of the Brazilian quilombola thinker Antonio Bispo (2015). (Quilombo is a term used to designate black communities in Brazil that have developed resistance practices to maintain ways of life based on the common use of the land.) For Bispo, what is happening is a war of synthetic cultures suffering from cosmophobia against organic cultures that know how to live and die well. The latter constantly affirm their connection to the land, which, in turn, has its own voice and has been shouting emphatically in the midst of this "climate of history" (Chakrabarty 2009, p. 197) that they do not just defend the land, they are the land defending itself. The paralysis of curriculum responses does not begin when schools fail to prepare for the devastating effects of Sars-Cov-2's journey through the channels of global hypermobility. Rather, it descends from when the curriculum was associated with an individualized 
training regime-what each person will be, what each wants to be, what content each will learn, and which competences each will develop. It is a policy of ontological enclosure acts of the human that extends to the curriculum, a policy that, in principle, is unable to gather the necessary conditions for re-enchanting the world, as Federici (2019, p. 189) invites us to do in order to reclaim "our relation with nature, with others, and with our bodies".

\section{Caring in the fog of cosmoecological webs}

In a television interview on a program titled "The Bats Are Not to Blame" (Walsh and Cotovio 2020), Andrew Cunningham, professor at the Zoological Society of London, states that "The underlying causes of zoonotic spillover from bats or from other wild species have almost always-always - been shown to be human behavior". I do not dwell on Cunningham's thesis on the relationship between the large-scale commercialization of wild animals, the ecology of bats, deforestation, and the emergence of Sars-Cov-2. However, in a previous study, Luis and other authors (2015), including Cunningham, wrote about what they call the ecological network, a concept that bridges mathematics, biology, and the social sciences to describe the processes of interaction between species. In it, the authors speak of cross-species communities rather than individuals of a species. The final paragraph is worth highlighting:

Our networks connect hosts by their shared viruses. [...] Our study highlights the interconnectedness of species with respect to viruses and shows the benefits of examining pathogens in a community ecology context at several scales. Our analyses suggest that unique bat characteristics figure importantly in sharing and spreading viruses, lending quantitative support for bats' special status in zoonotic virus emergence and demonstrating which characteristics affect reservoir potential. Practically, our analyses may help guide future surveillance [...] while conserving bats' important roles in ecosystem services such as pest management, plant pollination and seed dispersal. (p. 161)

The crisis of Covid-19 is the stage for a feral history of multispecies life in which political and economic activities form webs with ecological processes. This is further illustrated by how bats shine in symbiosis with various coronaviruses in "a strong signal for co-evolution" (Jóffrin et al. 2020, p. 3). In fact, the latest report by the International Committee for Taxonomy of Viruses records 6590 virus species (ICTV 2019). Not everything in this "new virological age" (Zhang et al. 2018, p. 1168) can be understood by the painful effects caused in humans. However, it should not be difficult to imagine what the devastating loss of habitats to this virosphere means. Here, I allude to the concept of feral dynamics proposed by Bubdant and Tsing (2018) to describe the "anthropogenic landscapes set in motion not just by the intentions of human engineers but also by the cascading effects of more-than-human negotiations" (p. 1). As the horror of the wholesale massacre of biodiversity finds connections with the emergence of viral diseases, what Tsing (2015b) once called salvage accumulation feeds on "Life turned to Nonlife and transformed into a new kind of species war-the aggressive rotting undead against the last redoubt of Life" (Povinelli 2016, p. 37). There, where the transfer of "virological 'darkmatter"” (Zhang et al. 2018 , p. 1172) appears on the fringes of threatened forests, in the interstices of interspecies friction, there is a tenacious transition from symbiosis to war, exposing life to diseases, suffering, and death. 
On the other side of the Pacific, in the Western Amazon between Brazil, Bolivia, and Peru, the Huni Kuin, one of the Amerindian peoples of the Pano linguistic branch, although they are called bat people (Kashinawa), do not include bats in their food. Lagrou (2020) comments that because they believe bats carry yuxin, Huni Kuin do not consume them. A category of a conceptual system that is difficult to translate, yuxin describes a vital force and a kind of image-being capable of altering the physical shape of the body, which transits between different forms and has the power to perform an inter-specific mutation (Lagrou 1998). Tangled in the daily lives of Huni Kuin, yuxin is at the heart of disease. What is hunted is not an object, it is a subject and can also kill in such a way that "all predation involves counter-predation" (Lagrou 2020). It is not for nothing that hunting is seen as a diplomatic negotiation established in the face of otherness and achieving an entire ethic. The Huni Kuin, therefore, conceive the disease as "a dangerous and uncontrolled process of othering" (Lagrou 1998, p. 45). We are facing a trans-specific sociality in which different types of subjects are woven together in a topological network of perspectives that is far from isolating the individual against a passive background-Nature.

This cosmological coordinate finds echo in Keck's (2020) argument that the virus is not a simple, invisible wild entity to observe, isolated and stabilized under a microscope inside a laboratory, but a warning signal whose transmission among the bodies of animals is followed studied by virologists. The author notes that this tracking is a kind of hunt, as there is only uncertainty in such interspecies relationships. In this regard, I do not mention the Huni Kuin to affirm that they think like ecologists, or vice-versa, so that "the future of the settler is ensured through the absorption of those aspects of Indigenous knowledge" (Tuck and Gaztambide-Fernández 2013, p. 73). I foment this encounter, purely virtual, but no less real, because of my strong sense that the map of conceptual distinctions we curriculum researchers have inherited from the humanities is crumbling as we respond to the Covid-19 crisis. This feedback loop, which connects animals, viruses, farms, forests, and cities, and very different people and places, is no stranger to any of these worlds. With this echo, I can imagine a speculative crossing of the curricular responses toward the fog of Stengers's (2010) cosmopolitical assembly, a fundamental proposition for realizing that "we are not alone in the world" (Stengers 2012, p. 9).

These cosmoecological webs provoke a debate about curriculum and subjectivity because one of the impediments to thinking about responsibility is the tenacity with which the separation between the self, other-than-human creatures, and even the Earth is sustained. With this concern in mind, I came across the concept of care as formulated by De La Bellacasa (2017) in the problematic field of thought and ethics. De La Bellacasa (2017) calls for care as part of a spreading support network for life, an affective state, a vital material action, and an ethical-political obligation that "involves material engagement in labours to sustain interdependent worlds" (De La Bellacasa 2012, p. 198). While various developments are possible, I will focus on the effect of one of them: the expansion of the ethical field to bring human beings down to "interdependent more than human relational webs" and to intensify "an ethical reorganization of human-nonhuman relations..., but what this means in terms of caring obligations that could enact nonexploitative forms of togetherness cannot be imagined once for all" (De La Bellacasa 2017, p. 24). This reorganization "is not a contract but a condition; even a pre-condition" (De La Bellasca 2012, p. 199). From this perspective, Covid-19's cruel devastation of life offers us another example of the continuing disaster of human rejection of interdependence at the limits of species and, as a corollary, of banishing care when we enter directly or indirectly into the life of others.

Care is not an unprecedented issue in curriculum studies. Jung (2015, p. iii) poses a question that inspires my formulation: "What might an education with self-care and 
care-for-others look like?" He points out that caring for others and for oneself can encourage students to create multiple paths by opening "a break in the unnecessary connection between our ethics and oppressive structures" (p. 149) through "intimate relationships... because self and other are ontologically interconnected and constantly changing, hand in hand" (p. 153). In addition to being designed to produce and extend gender norms, care promotes an interval for encounters without guarantees, "a set of vital but underappreciated strategies for enduring precarious worlds... providing spaces of hope in dark times" (Hobart and Kneese 2020, p. 2). In this perspective, power and powerlessness need not be experienced as opposed or immeasurable and political action implies that we always are vulnerable and exposed to otherness (Dean 2015). What I seek under the name of caring for the Earth recognizes both the vitality and the risk of this mutual ethical-political work between humans and other-than-human creatures from a cosmoecological perspective "situated within the largest dance of life which involves life and death, self and other, us and them" (Rose 2011, p. 28).

For all these reasons, care cannot be limited to a call for perfect and holistic relationships, let alone function as a safe conduit for some feeling of comfort or reward in accepting and feeling interdependence. I am thus led to face a problem: The history of Covid-19 is a good example of what Povinelli (2016) calls geontology, that is, the idea that different ontologies conceive the relationship between life and nonlife differently. She points to the limits of a vitalistic trend that views life as a constant process of reproducing, being born, growing, and dying that the presence of the virus takes to the limit. Turning to the aborigines, she shows how the Australian desert emerges as the result of events in a relational network of intentional reflection and action, not necessarily of living beings but of vital biochemical and geophysical strategies and encounters that allow rocks or rivers to continue to exist. Therefore, the other-than-human otherness will not always take the form of a living face to provoke ethical reactions. To use Caduff's (2015) vocabulary, our "cosmology of mutant strains" (p.15) leaves indelible ethical marks in an attempt to justify our belief that the ontological uniqueness of human beings is harassed, when in reality it was only erected in the rubble of a "social project whose purpose is to keep an arrangement of accumulation in place through the specific governance of difference and markets that stretches across human and nonhuman forms of existence" (Povinelli 2016, p. 249).

Care for the Earth materializes an ethical way for the curriculum to respond to the need to think about our interdependence and reciprocal fragility when, finally, we realize, even if against the grain, that we are thrown into planetary cosmoecological webs in continuous movement, bigger than we are and on which we depend to live and die. It is also a way of recognizing that the intersubjective constitution of this "we" is already inhabited by a whole other-than-human otherness with which we are intrinsically intertwined and obliged to negotiate and articulate. However, this indication leaves us with another question: How could the curriculum respond to a planet so haunted by the forces of colonial extraction? How could it make caring for the Earth an ethical experience arising out of our sensitivity and feeling that we are living within the fog of cosmoecological webs? How to produce at the same time a curriculum that affects not only knowledge but also our ontological relationality with other-than-human otherness?

The documentary The Pearl Button (2015), by Chilean filmmaker Patrício Guzmán, offered me a clue to how to answer these questions. There is something provocative about the film's metaphysical investigation: the use of images and sounds from the long Chilean coast, the rivers that cut the Andean mountain range, and the glaciers of the South Pacific contrasted with the stories told about the disappearance of the nomadic maritime Indigenous peoples of Patagonia and the transformation of the ocean into a cemetery for the 
bodies of those murdered by the dictatorial regime of Salvador Allende. The film's thesis is not only that water keeps the memory of the country's violent colonial history but that water carries a voice to tell it, to tell about the lives of those who have succumbed to it, displacing Spivak's question (1988): Can water, or even non-living creatures, speak? The film leads me to intuit that this deity called "patchy capitalism" (Tsing 2015b) is inseparable from an operation to legitimize the deadly devastations attributed to it and, in its wake, produce evaporation of our sensitivity to the intertwining of genocide and ecocide. In other words, it is a poisonous image that disarms our thinking to the point of not even showing the action of non-living things as an issue. It provides, as its mirror, an image of the planet and the cosmos that is so hypostatized that it is difficult to separate it from the project that sustains our responsibility.

Another unavoidable reference, in my view, is the theme of renouncing thought, proposed by Arendt (1999) in her account of the Eichmann trial in Jerusalem. Eichmann, according to her, was not a monster but a person like us. He makes the death of millions of people he did not even hate possible, placing duty and obedience above all else. The human agents of mass extermination during World War II were like that, a multitude of diligent people, like us, carrying out their duty but inconsequential.

When questioning why Chile never capitalized on its coastline, Guzmán's film suggests that it is because the water remembers the killing power of colonial history, of the tides returning to the coast the bodies that should have disappeared forever. Not wanting to have any relationship with the ethical, ecological and cosmological effects of colonial history does not mean, therefore, that there is no relationship whatsoever with the uses of that history or that it is possible to avoid responding to and being responsible for it. My use of Arendt thus seeks to block the poisons that the Covid-19 crisis continues to emit against our thinking and to dream that our curricular responses could echo the voices of the Earth, the viral signals, and the celestial bodies and compose relations of livability with them, where limits between life and nonlife are no longer evident, if they ever were.

The Pearl Bottom invites us to pay attention to the signs of water and stars, since materiality and meaning are mutually constituted. My point is that caring for the Earth cannot be the object of exposure, acquisition, or explanation by the curriculum. It is not a matter of telling students and teachers about the need to take care of the planet, but of their experiencing living acts of care. However, I do not want to disregard the fact that curricular responses now face the unprecedented physical isolation of children and young people. In considering this, I feel uncomfortable. As Le Grange (2014) points out, the active force of the curriculum for "open[ing] up multiple courses of life" has been swallowed up by the image of the course to be performed, leading "to the ossification of potential movements, thwarting of experimentation, freezing of living and domestication of self" (p. 1288). This image has the effect of dulling our ability to tell other stories—stories through which the curriculum can achieve a relational knowledge of life and open an escape route out of the vicious cosmophobic circle of developmentalism and its counterparts. Stories of of a furious Earth with which we must learn to work and whose intrusion shows that scientific practices, organic cultural practices, and cosmopolitical practices can no longer be separated. Indeed, Stengers (2015, p. 47) refers to "Gaia intrusion" as a living Earth that responds to the predatory expansion of capitalism and is indifferent to human reasons, emerging as "an unprecedented or forgotten form of transcendence".

Far from the belief that trouble resides in generalized human action, I began this essay with the question of how uncertainty left us lost in the fog of the cosmoecological webs. My answer is neither guiding nor comforting. It is even painful in some ways. It is no longer possible to separate internality and externality in resource management strategies 
for the governance of capitalist colonialism. As such, caring for the Earth means taking a stand against violence and the power to kill that pushes the planet into the field of objectification. However, there is also a shift in language. All the talk about a war against a "killer strain lurking in the shadows" (Caduff 2015, p. 5) puts the field of security in charge of proposing answers. Care, on the other hand, transforms education into a restorative field of living in the face of dying together, of being affected by the magic of onto-epistemic processes involving many human and other-than-human creatures in the material continuation and permanent interrelation of sharing the biosphere. In the end, the Covid-19 crisis hints at possibilities for responding beyond simply creating restrictions, responses that are not just waiting resignedly for the next plague, for which we will have an increasingly prepared and efficient educational apparatus. Care for the Earth implies planetary responsibility by producing some glimpse of our being the result of these cosmoecological webs of mutual interdependencies.

\section{Respond planetarily}

This concluding section's title alludes to an essay by Spivak (2012) on how the "imperative to re-imagine the planet" (p. 335) is deeply ethical. Her argument is about educating ourselves while embracing "animism as well as the spectral white mythology of post-rational science" (p. 339). Her ideas thus deal with a non-totalizing imperative because the ontological relationship incorporated in them presents an ethical change "inscribing collective responsibility as ... mysterious and discontinuous - an experience of the impossible" (Spivak 2003, p. 102). I named this ethical work "caring for Earth" in order to indicate that the Earth is a displaced site for curriculum responsibility. The planet imagined as an astronomical body is nothing more than a fallen vision of ethics. Biogeophysical, ecological, and cosmological planetary processes are less inert than they seem at first and than we would like them to be, in consonance with what Clark (2011) calls a "dynamic, unpredictable planet" (p. 5). I would suggest that reimagining the curriculum in the face of the Covid-19 crisis from this planetary point of view is urgent because caring for the Earth requires making our actions tangible to ourselves, living with their effects, and not allowing a generalized climate of giving up to set in just because we are facing uncertainty. The backdrop of my invocation is a distinction between judicial definitions of the word "responsibility", including the distribution of guilt and the court of reason, and the ability to respond that was set forth by Haraway (2016). It is impossible to continue as if physical distance and political impotence exempted us from answering, as if abandoning otherness, delegating, or evading were the only answers, ones that involve renouncing thought.

I also found a clue to this final statement in Audre Lorde (2019): “The Master's tools will never dismantle the Master's house" (p. 137). My proposal is nothing more than an extrapolation of her argument about difference as a relationality both reciprocal and singular, as a necessary mantle for our creativity and the creation of a new future. She speaks of picking at scabs forming over colonial wounds in face of the usual avoidance of responsibility and also of how the community does not require replacing differences or presuming they do not exist. Thus, responding planetarily does not reside in searching for global efficiency in order to mitigate our circumstances but in calling for otherthan-human otherness. In Mbembe's (2020) terms, "We must answer here and now for our life on Earth with others (including viruses) and our shared fate". Responding planetarily thus causes another subject to be found. Not the one derived from a mitocosmological system centered on the anthropos, whose avatars, with their lethal power and 
justifications for it, their propaganda and their anesthetizing poison, have so far offered us. It was in the face of individuals who were safe and comfortable but also able to commit "a crime against creation itself" (Herzog 2010, p. 2) in the name of political issues and to sleep the sleep of the righteous, that I felt "the shame of being human", as Primo Levi wrote (1988). Rather, this regards a subject who responds for the planet because of what is happening on it and because what happens to one happens to both.

Our "matter is always already an ongoing historicity" (Barad 2003, p. 818), it brings along its baggage, it is not under control, and it abandons the subject to the whims of alterity. By avoiding this relational genealogy, we can probably lose sight of the imbrications between curriculum, responsibility, and "an event of cosmic dimensions" (Herzog 2010). It is problematic to simplify and confuse curricular responses to the Covid19 crisis with solutions. At the same time, if we don't produce such responses, we not only fail to make education work against the ongoing devastation, we also amplify the devastation by exempting educational institutions from doing support work and caring for differences. In Paraisópolis, for example, a poor neighborhood (bairro favelizado or "slum") in the city of São Paulo, Brazil, schools were transformed into shelters for receiving and isolating homeless people or those who live in small houses. Additionally, schools also host a monitoring project for twenty thousand neighborhood houses, involving local leaders, teachers, students and doctors.

If a curriculum-creating force comes from the intersubjective mesh it enacts, when the possibility of going ahead without working with teachers and students to produce answers is defended, we become deader than the dead. And without ethical sensitivity, we lose our ability to respond. These planetary responses can be rooted in a myriad of possibilities, they can be localized and contingent, but above all, they must be irreplaceable and indelegable, woven into lines and tensions from other times and spaces. Their scalability is certainly very different from the totalizing globalization of the disease. In fact, these answers develop a sort of vaccine to prevent curricular imagination from becoming captive to the geometric coordinates of the economization of life, which are so dear to the sectors involved in disaster management.

Care is an irreplaceable component of the responsibility for inhabiting the planet, which, Parreñas (2018, p. 117) notes, is "forced to live with humans and their traits", adding that under "these circumstances, living together also ... means to die slowly together". Care makes us accountable as individuals dependent on the Earth, both from within and as constituted by the cosmoecological webs that animate it. Care is an ability to bow before the face of otherness, to be invaded by it, to be inherently vulnerable to uncertainty through our responses. There are worlds beyond what we know; it is in the midst of what we do not know, in the midst of the nebulousness that we can respond. Responding planetarily is an effort not only to live on the planet but to do so in a way that brings the stories of intersubjective ties to the curriculum in order to purge disease and restore health, and that care can have the effect of knowledge for us. Therefore, the work of caring in a pandemic is not restricted to health professionals. The care of the curriculum responds to the violent cosmoecology of capitalist colonialism by unblocking the political action of just being defensive in the face of war. What we call subject formation is nothing more than caring for life and death intertwined within dense, tangled, and cacophonic stories, in which movements of violation and the search for alternatives coexist to "allow the kind of joy in daunting circumstances that allow us to work on changing the world" (Shotwell 2016, p. 201).

An observation by Stengers (2015) is appealing: The time of struggle and the time of creating life, thought, and joy can no longer be ordered as a before and an after. Both need: 
[to] learn to work together without confusion, through relaying, prolonging and reciprocal apprenticeship to the art of paying attention, in a cacophony of sound and fury emanating from a very big litter whelped in shared but nonmimetic suffering and issuing in movements for flourishing yet to come. (p. 105)

We are now living inside other-than-human stories on the planet. Developing responses planetarily can no longer wait. Perhaps caring for the Earth as someone who hears its warning signs and even its grief and pain is our last chance.

\section{References}

Arendt, H. (1999). Eichmann em Jerusalém: Um relato sobre a banalidade do mal [Eichmann in Jerusalem: A report on the banality of evil]. São Paulo: Companhia das Letras.

Barad, K. (2003). Posthumanist performativity: Toward an understanding of how matter comes to matter. Signs, 28(3), 802-831.

Berardi, F. (2011). After the future. Stirling, UK: AK Press.

Bispo, A. (2015). Colonização, Quilombos: Modos e significações [Colonization, quilombos: Modes and meanings]. Brasilia: INCTI.

Bubandt, N., \& Tsing, A. (2018). Feral dynamics of post-industrial ruin: An introduction. Journal of Ethnobiology, 38(1), 1-7.

Butler, J. (2004). Precarious life: The powers of mourning and violence. New York, NY: Verso.

Caduff, C. (2015). The pandemic perhaps: Dramatic events in a public culture of danger. Oakland, CA: University of California Press.

Chakrabarty, D. (2009). The climate of history: Four theses. Critical Inquiry, 35(2), 197-222.

Clark, N. (2011). Inhuman nature: Sociable life on a dynamic planet. London: Sage.

CNE [Conselho Nacional de Educação] (2020). Parecer CNE/CP no 5/2020. Brasilia: Ministro de Estado da Educação. http://portal.mec.gov.br/conselho-nacional-de-educacao/atos-normativos--sumulas-parec eres-e-resolucoes/33371-cne-conselho-nacional-de-educacao/85201-parecer-cp-2020.

Dean, C. (2015). Atrocity photographs, dignity, and human vulnerability. Humanity: An International Journal of Human Rights, Humanitarianism, and Development, 6(2), 239-264.

De La Bellacasa, M. (2012). Nothing comes without its world: Thinking with care. The Sociological Review, $60(2), 197-216$.

De La Bellacasa, M. (2017). Matters of care: Speculative ethics in more than human worlds. Minneapolis, MN: University of Minnesota Press.

Derrida, J. (2008). The animal that therefore I am. New York, NY: Fordham University Press.

Federici, S. (2019). Re-enchanting the world: Feminism and the politics of the commons. Oakland, CA: PM Press.

Fox, N. (2020, March 9). Money, markets and trade caused coronavirus pandemic. Sociology Lens. https:// www.sociologylens.net/topics/political-economic-sociology/money-markets-trade-caused-coronavirus-pandemic/29787.

Guzmán, P. (2015). The pearl button [Documentary film]. New York, NY: Kino Lorber.

Haraway, D. (1992). The promises of monsters: A regenerative politics for inappropriate/d others. In L. Grossberg, C. Nelson \& P. Treichler (Eds.), Cultural studies (pp. 295-337). London: Routledge.

Haraway, D. (2016). Staying with the trouble: Making kin in the Chthulucene. Durham, NC: Duke University Press.

Helmreich, S. (2009). Alien ocean: Anthropological voyages in microbial seas. Berkeley, CA: University of California Press.

Herzog, W. (2010). On the absolute, the sublime, and ecstatic truth. GmbH. https://www.bu.edu/arion/onthe-absolute-the-sublime-and-ecstatic-truth/.

Hobart, H., \& Kneese, T. (2020). Radical care: Survival strategies for uncertain times. Social Text, 38(1), $1-16$.

ICTV [International Committee on Taxonomy of Viruses] (2019). Master species list 2019. ICTV. https:// talk.ictvonline.org/files/master-species-lists/m/msl/9601.

Jóffrin, L., Goodman, S., Wilkinson, D. A., Ramasindrazana, B., Lagadec, E., Gomard, Y., Le Minter, G., Dos Santo, A., Schoeman, C., Sookhareea, R., Tortosa, P., Julienne, S., Gudo, E., Mavingui, P. 
\& Labarbenchon, C. (2020). Bat coronavirus phylogeography in the Western Indian Ocean. Scientific Reports, 10, 1-9. https:/www.ncbi.nlm.nih.gov/pmc/articles/PMC7181612/.

Jung. J. (2015). Self-care and care-for-others in education [Unpublished doctoral dissertation]. Vancouver, BC: University of British Columbia. http://hdl.handle.net/2429/53164.

Keck. F. (2020). Avian reservoirs: Virus hunters and birdwatchers in Chinese sentinel posts. Durham, NC: Duke University Press.

Knorr-Cetina, K. (1999). Epistemic cultures: How the sciences make knowledge. Cambridge, MA: Harvard University Press.

Lagrou, E. (1998). Cashinahua cosmovision: A perspectival approach to identity and alterity [Unpublished doctoral dissertation]. St Andrews, UK: University of St Andrews. http://hdl.handle.net/10023/1676.

Lagrou, E. (2020, April 14). Nisun: A vingança do povo morcego e o que ele pode nos ensinar sobre o novo coronavírus [Nisun: The revenge of the bat people and what it can teach us about the new coronavirus]. Blog da BVPS. https://jornalistaslivres.org/nisun-a-vinganca-do-povo-morcego-e-oque-ele-pode-nos-ensinar-sobre-o-novo-coronavirus/.

Latour, B. (2002). War of the worlds: What about peace? Chicago, IL: Prickly Paradigm Press.

Latour, B. (2011). Science in action: How to follow scientists and engineers through society. Cambridge, MA: Harvard University Press.

Latour (2017). Facing Gaia: Eight lectures on the new climatic regime. Cambridge, UK: Polity.

Le Grange, L. (2014). Currere's active force and the Africanisation of the university curriculum. SAJHE, 28(4), 1283-1294.

Levi, P. (1988). The drowned and the saved. New York, NY: Summit Books.

Lorde, A. (2019). Irmã outsider: Ensaios e conferências [Sister outsider: Rehearsals and speeches]. Belo Horizonte: Autêntica.

Lowe, C. (2010). Viral clouds: Becoming H5N1 in Indonesia. Cultural Anthropology, 25(4), 625-649.

Luis, A., O’Shea, T. J., Hayman, D. T., Wood, J. L. N., Cunningham, A. A., Gilbert, A., et al. (2015). Network analysis of host-virus communities in bats and rodents reveals determinants of cross-species transmission. Ecology Letters, 18, 1153-1162.

Lynteris, C. (2019). Human extinction and the pandemic imaginary. London: Routledge.

Mbembe, A. (2020, April 13). The universal right to breathe. Critical Inquiry. https://critinq.wordpress. com/2020/04/13/the-universal-right-to-breathe/.

Myers, N. (2015). Rendering life molecular: Models. Durham, NC: Duke University Press.

OECD (2020). A framework to guide an education response to the Covid-19 pandemic of 2020. Paris: OECD.

Parreñas, J. (2018). Decolonizing extinction: The work of care in orangutan rehabilitation. Durham, NC: Duke University Press.

Povinelli, E. (2016). Geontologies: A requiem to late liberalism. Durham, NC: Duke University Press.

Rose, D. (2011). Wild dog dreaming: Love and extinction. Charlottesville, VA: University of Virginia Press.

Simondon, G. (1992). The genesis of the individual. In J. Crary \& S. Kwinter (Eds.), Incorporations (pp. 296-319). New York, NY: Zone.

Shotwell, A. (2016). Against purity: Living ethically in compromised times. Minneapolis, MN: University of Minnesota Press.

Spivak, G. (1988). Can the subaltern speak? In C. Nelson \& L. Grossberg (Eds.), Marxism and the interpretation of culture (pp. 271-313). London: Macmillan.

Spivak, G. (2003). Death of a discipline. New York, NY: Columbia University Press.

Spivak, F. (2012). An aesthetic education in the era of globalization. Cambridge, MA: Havard University Press.

Stengers, I. (2010). Cosmopolitics II. Minneapolis, MN: University of Minnesota.

Stengers, I. (2012). Reclaiming animism. e-flux, 36. https://www.e-flux.com/journal/36/61245/recla iming-animism/.

Stengers, I. (2015). In catastrophic times: Resisting the coming barbarism. London: Open Humanities Press.

Tsing, A. (2015a). In the midst of disturbance: Symbiosis, coordination, history, landscape [Conference session]. Association of Social Anthropologists Annual Conference, Exeter, UK. https://www. theasa.org/downloads/publications/firth/firth15.pdf.

Tsing, A. (2015). The mushroom at the end of the world: On the possibility of life in capitalist ruins. Princeton, NJ: Princeton University Press.

Tuck, E., \& Gaztambide-Fernández, R. (2013). Curriculum, replacement, and settler futurity. Journal of Curriculum Theorizing, 29(1), 72-89. 
Wallace, R. (2016). Big farms make big flu: Dispatches on influenza, agribusiness, and the nature of science. New York, NY: Monthly Review Press.

Wallace, R. (2020). Dead epistemologists: On origins of Covid-19. New York, NY: Monthly Review Press.

Walsh, N., \& Cotovio, V. (2020, March 19). Bats are not to blame for coronavirus. Humans are. CNN Health. https://edition.cnn.com/2020/03/19/health/coronavirus-human-actions-intl/index.html.

Weaver, J. (2019). Science, democracy, and curriculum studies. Dordrecht: Springer.

UNESCO (2020). Global education coalition. Paris: UNESCO. https://pt.unesco.org/covid19/globa leducationcoalition.

Zhang, Z., Shi, M., \& Holmes, E. (2018). Using metagenomics to characterize an expanding virosphere. Cell 172, 1168-1172. https://www.cell.com/action/showPdf?pii=S0092-8674\%2818\%2930220-4.

Publisher's Note Springer Nature remains neutral with regard to jurisdictional claims in published maps and institutional affiliations.

Thiago Ranniery is Full Professor of Science Education at Federal University of Rio de Janeiro, Brazil. He is a Vice-Director of the Faculty of Education and member of the Multidisciplinary Working Group to Confront Covid-19 at the same university. A Fellow of the Foundation for Research Support of the State of Rio de Janeiro, he coordinates a research team on Curriculum, Ethics and Difference. His research areas are curriculum, difference, and science and technology, informed by post-colonial, post-human, and queer studies. 